\title{
Outbreaks of vesicular disease caused by Vaccinia virus in dairy cattle from Goiás State, Brazil (2010-2012) ${ }^{1}$
}

\author{
Fabiano J.F. de Sant'Ana ${ }^{2 *}$, Antônio do A. Leal ${ }^{3}$, Rogério E. Rabelo ${ }^{4}$, Valcinir A.S. Vulcani ${ }^{5}$, \\ Jair A. Ferreira Junior ${ }^{2}$, Juliana F. Cargnelutti ${ }^{6}$ and Eduardo Furtado Flores ${ }^{6}$
}

ABSTRACT.- Sant'Ana F.J.F., Leal A.A., Rabelo R.E., Vulcani V.A.S., Ferreira Junior J.A., Cargnelutti J.F. \& Flores E.F. 2013. Outbreaks of vesicular disease caused by Vaccinia virus in dairy cattle from Goiás State, Brazil (2010-2012). Pesquisa Veterinária Brasileira 33(7):860-866. Laboratório de Patologia Veterinária, Universidade de Brasília, Brasília, DF 70910-900, Brazil. E-mail: santanafj@@yahoo.com

Cases of vesicular and exanthematic disease by Vaccinia virus (VACV) have been reported in dairy herds of several Brazilian regions, occasionally also affecting humans. The present article describes eight outbreaks of vesicular disease caused by VACV in dairy herds of six counties of Goiás state, Midwestern Brazil (2010-2012), involving a total of 122 cows, 12 calves and 11 people. Dairy cows ( 3 to 9 years old) were affected in all cases and calves ( 2 to 9 months old) were affected in five outbreaks, presenting oral lesions. The morbidity ranged between 8 and 100\% in cows, and 1.5 to 31\% in calves. In the cows, the clinical signs started with vesicles $(2-7 \mathrm{~mm})$, painful and coalescent papules $(3-8 \mathrm{~mm})$, which resulted in ulcers (5$25 \mathrm{~mm}$ ) and scabs in teats, and, occasionally, in the muzzle. The clinical course lasted from 16 to 26 days. The histopathology of bovine skin samples revealed superficial perivascular inflammatory infiltrate of lymphocytes, plasma cells, neutrophils, macrophages and multifocal areas of acanthosis, spongiosis, hipergranulosis and parakeratotic or orthokeratotic hyperkeratosis with adjacent focally extensive ulcers. Eosinophilic inclusion bodies were noted in the cytoplasm of the keratinocytes. PCR to $v g f$ gene of Orthopoxvirus was positive in samples collected from all outbreaks, and in some cases, genomic VACV sequences were identified by nucleotide sequencing of the PCR amplicons. Infectious virus was isolated in cell culture from scabs from one outbreak. Antibodies to Orthopoxvirus were detected in at least 3 or 4 animals in most outbreaks, by ELISA (outbreaks 1, 2, 3, 4, 5 and 7) or virus-neutralization (outbreak 6). Neutralizing titers ranging from 8 to 64 in outbreak 6. In all outbreaks, VACV infection was suspected based on the clinical and pathological findings and it was confirmed by laboratory tests. Upon the etiological confirmation, other agents associated with vesicular disease were discarded. In all outbreaks, at least one milker who handled the affected cows developed malaise, headache, fever, painful vesico-pustular lesions mainly in the hands, but also in the neck and nose. These results confirm the circulation of VACV in the region and call attention for a correct diagnosis and the adoption of prophylactic and control measures.

INDEX TERMS: Vaccinia virus, diseases of cattle, VACV, epidemiology, Orthopoxvirus.

\footnotetext{
${ }^{1}$ Received on February 22, 2013.

Accepted for publication on June 19, 2013.

${ }^{2}$ Laboratório de Patologia Veterinária (LPV), Universidade de Brasília (UnB), Campus Universitário Darcy Ribeiro, L4 Norte, Asa Norte, Brasília, DF, 70910-900, Brazil. *Corresponding author: santanafjf@yahoo.com

${ }^{3}$ Agência Goiana de Defesa Agropecuária, Av. Portugal 591, Goiânia, GO 74140-020, Brazil.

${ }^{4}$ Setor de Cirurgia de Grandes Animais, CAJ-UFG, Jataí, GO 75801-615, Brazil.

${ }^{5}$ Laboratório de Anatomia, CAJ-UFG, Jataí, GO.

${ }^{6}$ Setor de Virologia, Departamento de Medicina Veterinária Preventiva, Universidade Federal de Santa Maria (UFSM, Camobi, Santa Maria, RS 97105-900, Brazil.
}

RESUMO.- [Surtos de doença vesicular causados pelo Vaccinia virus em bovinos de leite no Estado de Goiás, Brasil (2010-2012).] Casos de doença vesicular e exantemática associados ao Vaccinia virus (VACV) têm sido descritos em rebanhos leiteiros em diversas regiões do Brasil, ocasionalmente afetando também os ordenhadores. Este artigo descreve oito surtos de doença vesicular associados ao VACV ocorridos em rebanhos leiteiros de seis municípios do estado de Goiás (2010-2012), com o envolvimento de 122 vacas em lactação, de 12 bezerros e de 11 pessoas. Vacas em lactação (3-9 anos de idade) foram afetadas 
em todos os casos. Em cinco rebanhos, bezerros de 2-9 meses apresentaram lesões orais. A morbidade nos rebanhos variou entre oito e $100 \%$ (vacas) e entre 1,5 e $31 \%$ (bezerros). As lesões iniciavam como vesículas $(2-7 \mathrm{~mm})$ ou pápulas doloridas e coalescentes $(3-8 \mathrm{~mm})$, que progrediam para úlceras $(5-25 \mathrm{~mm})$ e crostas, localizadas principalmente nas tetas e, eventualmente, no focinho das vacas. 0 curso clínico variou entre 16 e 26 dias. Histopatologia de amostras de pele coletadas de bovinos revelou dermatite perivascular superficial com infiltrado de linfócitos, neutrófilos, plasmócitos e macrófagos, além de áreas multifocais de acantose, espongiose, hipergranulose e hiperceratose ortoceratótica ou paraceratótica com úlceras focalmente extensas. No citoplasma dos ceratinócitos adjacentes às úlceras, observaram-se numerosos corpúsculos de inclusão eosinofílicos. Em todos os surtos, amostras de lesões cutâneas dos bovinos foram positivas para o gene $v g f$ dos Orthopoxvirus por PCR, e em alguns casos, a identificação do VACV foi confirmada por sequenciamento de nucleotídeos dos amplicons. 0 vírus foi detectado por isolamento em cultivo celular em um dos surtos e, pelo menos 2 a 3 vacas por rebanho, apresentaram sorologia positiva para Orthopoxvirus pelos testes de ELISA (surtos 1, 2, 3, 4, 5 e 7) e soroneutralização (surto 6). No surto 6, os títulos de anticorpos neutralizantes variaram de 8 a 64 . 0 diagnóstico da infecção pelo VACV, inicialmente suspeito com base nos achados clínicos e patológicos, foi confirmado em todos os surtos por exames laboratoriais. Em todos os surtos, pelo menos um ordenhador que teve contato com os bovinos afetados apresentou mal-estar geral, febre alta, dor de cabeça e lesões vesiculo-pustulosas doloridas, principalmente nas mãos, mas também no pescoço e nariz. Esses resultados confirmam a circulação do VACV no rebanho bovino da região centro-oeste, alertando para necessidade de diagnóstico correto e adoção de medidas profiláticas e de controle.

TERMOS DE INDEXAÇÃO: Vaccinia virus, doenças de bovinos, VACV, epidemiologia, Orthopoxvirus.

\section{INTRODUCTION}

The genus Orthopoxvirus (OPV) belongs to the family Poxviridae, subfamily Chordopoxvirinae and includes several viruses that cause vesicular skin disease in animals and/or man: Vaccinia virus (VACV), Cowpox virus (CPXV), Smallpox virus (or Variola virus, VARV) (eradicated in 1979), among others (Mercer et al. 2007). OPVs are distributed worldwide and are responsible for important impact in public and animal health (Esposito \& Fenner 2001).

VACV is the prototype OPV and is associated with vesicular and exanthematic disease in cattle. VACV infection is zoonotic and transmission to man usually occurs through handling or milking affected cows (Smith 2007). Lesions in VACV-infected cattle are most frequently observed in teats and udders of milking cows, and in the mouth of suckling calves (Leite et al. 2005, Lobato et al. 2005, Silva et al. 2008). In man, skin lesions are painful and occur mainly on the hands and fingers: nodular swellings, papules, pustules, ulcers and scabs. Systemic disease with lymphadenopathy, headache and fever is occasionally observed in affected persons (Lobato et al. 2005, Megid et al. 2008).

In Brazil, a number of cases of VACV-associated disease have been reported in the recent years, affecting dairy cows and milkers, especially in the Southeast region (Lobato et al. 2005, Trindade et al. 2007, Megid et al. 2008, Kroon et al. 2011). These reports, in general, describe the clinical presentation in animals and man, accompanied by molecular identification and characterization of the isolates (Damaso et al. 2000, Trindade et al. 2003, Leite et al. 2005, Lobato et al. 2005). Moreover, characterization of field isolates regarding the nucleotide sequence of the hemagglutinin gene (HA), phenotype in vitro and in a mouse model indicate that Brazilian VACV isolates belong to two different genogroups (type 1 and 2) (Kroon et al. 2011). The origin of these VACV remains unknown. However, in one Brazilian VACV outbreak, virus particles and anti-Orthopoxvirus antibodies were detected in tissues and sera from semi-domestic rodents, suggesting a possible link between farm animals and wild reservoirs (Abrahão et al. 2009). Experimental infection of cows with VACV resulted in viral spread in the feces (Guedes et al. 2012, Rivetti Jr et al. 2013). Mice exposition to VACV contaminated feces of cows resulted in virus DNA detection in blood and feces of mice, as well as neutralizing antibodies to VACV after 20 days post exposition, suggesting that exposure to bovine feces could be considered a risk factor for the spread of VACV (D'Anunciação et al. 2012, Rivetti Jr et al. 2013). Although some pathogenic aspects of the VACV experimental infection in cows has been recently studied (Rivetti Jr et al. 2013), most of these studies lack a detailed characterization of pathological aspects of the bovine natural infection.

Vesicular and exanthematic diseases in cattle represent a target of constant attention since they may be misdiagnosed with foot-and-mouth disease (FMD). Thus, proper diagnosis and clinic-pathological characterization of vesicular disease in cattle is imperative in order to distinguish among the vesicular diseases affecting cattle, particularly FMD (Brown et al. 2007). Cases of vesicular disease have been rarely reported in Goiás state (Nagasse-Sugahara et al. 2004), the second largest milk producer in Brazil. It is suspected that such cases do occur in the field, yet are under seen or neglected and not reported. Thus, the present article describes the epidemiological, clinical, and pathological findings of eight outbreaks of VACV infection affecting cattle and milkers in Goiás State, Midwestern Brazil.

\section{MATERIALS AND METHODS}

Eight outbreaks of vesicular disease occurred between June 2010 and June 2012 in six counties in Goiás State, Brazil. The total area of the affected counties is $13,507.797 \mathrm{~km}^{2}$. In all cases, epidemiological investigation (such as type of milking procedure, number and age of milkers, breed of cows, daily milk production, among others) was conducted in the affected farms and the animals were clinically examined. After local anesthesia, samples of cutaneous, muzzle, or oral lesions were collected of 4-5 cows/farm for histopathology and laboratory tests. Histological samples were fixed in $10 \%$ buffered formalin and processed for routine histopathological examination upon hematoxylin and eosin staining. Additional 
samples of scabs and papules were collected and maintained in sterile microtubes under freezing or refrigeration and sent to virus isolation and polymerase chain reaction (PCR) for detection of OPV and, eventually, for parapoxvirus. Peripheral blood from animals was collected to obtain serum and research of anti-Orthopoxvirus antibodies. The scabs and sera samples were processed in two different diagnosis laboratories (Setor de Virologia da Universidade Federal de Santa Maria, Rio Grande do Sul, or Embrapa Gado de Leite, Minas Gerais). Samples from outbreaks 6 were submitted to seroneutralization test (SN) according to Cargnelutti and collaborators (2012a), and the other samples were analyzed by ELISA (Silva-Fernandes et al. 2009) to detect IgG anti-Orthopoxvirus (Table 1).

For virus isolation, scabs were homogenized, ressuspended to $10 \%$ (weight-volume) in culture medium and inoculated onto monolayers of Vero cells, and submitted to three passages of five days each. Every day, the inoculated cultures were monitored for cytopathic effect. Total DNA was extracted from scabs using DNAzol reagent (Invitrogen, Life technologies, Carlsbad, CA) according to manufacture instruction, and submitted to PCR for OPV using primers for $v g f$ gene and conditions described by Abrahão et al. (2010) at the UFSM laboratory or the reagents and conditions described by Fonseca et al. (1998) at the Embrapa laboratory. Total DNA extracted from Vero cells infected with VACV-Pelotas
1 virus (P1V) was used as positive control of the PCR for OPV. Occasionally, total DNA of OPV negative samples were submitted to a PCR for parapoxvirus, using primers for the $B 2 L$ gene according to Inoshima et al. (2000). Total DNA extracted from contagious ecthyma scabs were used as positive control. Positive samples at PCR to VACV were submitted to nucleotide sequencing (MegaBACE sequencer, Amersham Biosciences, Piscataway, NJ) to identify the virus species.

\section{RESULTS}

The disease was diagnosed in six Goiás counties (Varjão, Buriti Alegre, São João da Paraúna, Pontalina, Edéia, and Mineiros) affecting eight milk farms that used hand milking. Cows ( 3 to 9 years old) were affected in all farms and, in five outbreaks, calves presented oral lesions (Table 1). The ratio of total affected to animals in total in the herds ranged from 6/121 to 40/294 (Table 1). The daily milk production in all properties ranged between 10 to 20 liters/cow.

The outbreaks 1 to 3 occurred in the same county (Varjão), affecting nearby farms (1 to $3 \mathrm{~km}$ ). The milk of these farms was collected daily by the same milk truck, possibly indicating an epidemiological link. All eight outbreaks oc-

Table 1. Clinical and laboratorial data of eight outbreaks of bovine vesicular disease associated to VACV infection in Goiás State, Brazil (2010-2012)

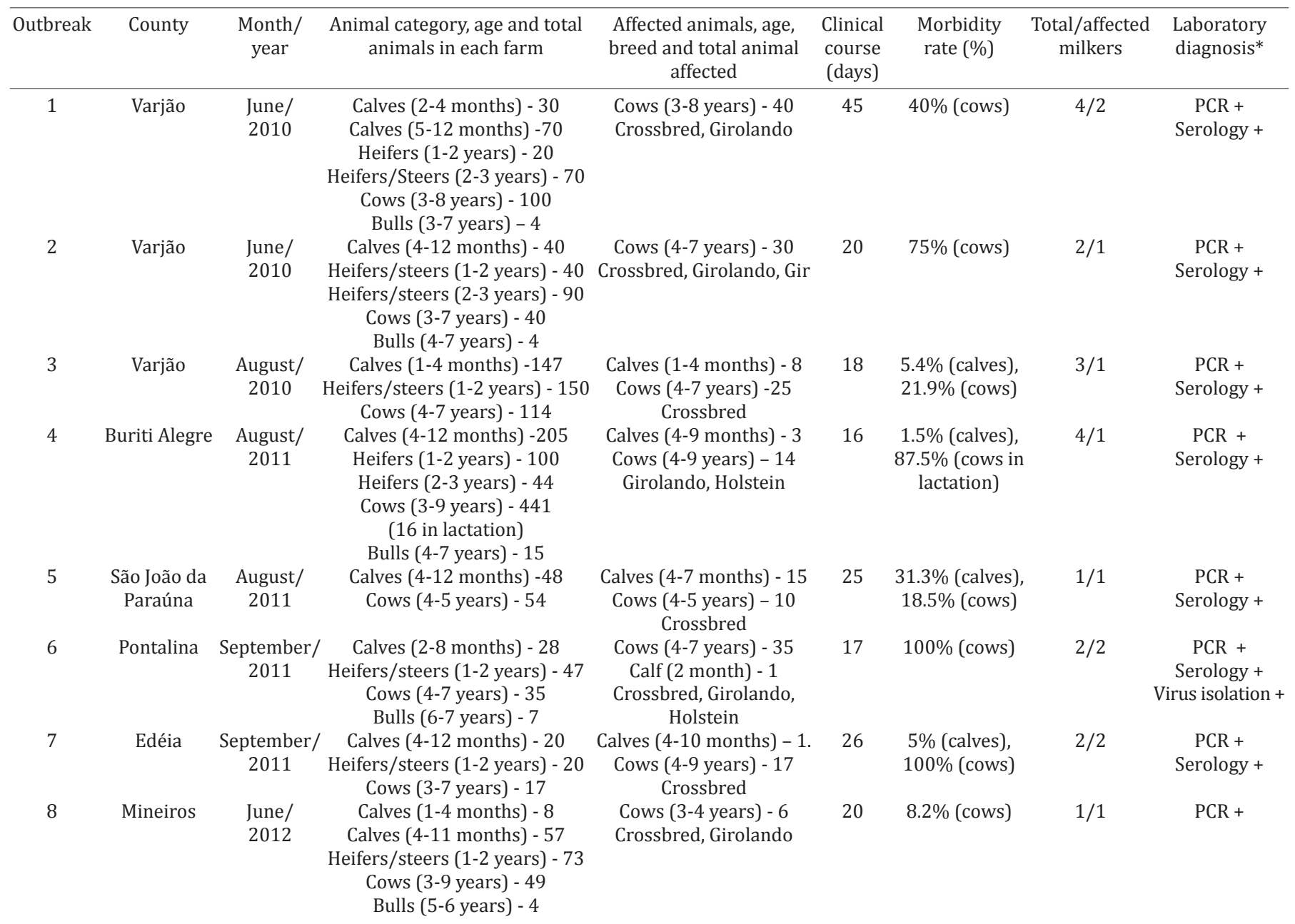

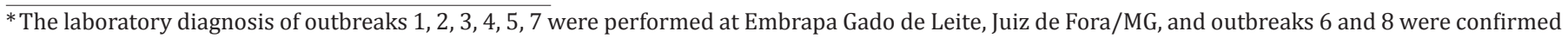
at Setor de Virologia, Universidade Federal de Santa Maria/RS. 
curred in the dry season of the respective years. The morbidity rate ranged from 8.2 to $100 \%$ of the lactating cows and from 1.5 to $31.3 \%$ of the calves. The epidemiological data are shown in Table 1.

In all cases, the main signs began with vesicles $(2-7 \mathrm{~mm}$ in diameter) or reddish, gray or whitish coalescent painful papules (3-8mm in diameter) and progressed to coalescent ulcers (5-25mm in diameter) (Fig.1) and gray or brown scabby proliferative lesions localized on the teats (cows). Ulcers restricted to the hard palate and gums were observed in calves. The clinical course ranged from 16 to 26 days, with the exception of outbreak 1 , where the clinical course - considering all affected animals in the herd - extended for approximately 45 days. In addition, in outbreak 3 , few cows presented numerous scabby lesions affecting the muzzle. In the cases with acute lesions, severe swelling of the teats was observed (Fig.1). In general, the teat lesions were multifocal and affected three or all teats of each cow, regressing approximately 15 to 21 days after the onset. A few days after the appearance of the first lesions (papules and vesicles), coalescent scabby ulcers were observed. Initially, in some cases, a mild serous secretion was observed in the ulcerative lesions that occasionally dried up, originating scabs. Affected cows presented severe local pain and did not allow the completion of milking, leading to interruption of lactation and, occasionally, to secondary mastitis.

Histologically, multifocal areas of moderate to severe acanthosis, spongiosis, hypergranulosis and parakeratotic or orthokeratotic hyperkeratosis with adjacent focally extensive ulcers were observed in the epidermis (Fig.2). Numerous $3-8 \mu \mathrm{m}$, circular, eosinophilic inclusion bodies were noted in the cytoplasm of the keratinocytes, mainly near of the areas showing acanthosis or necrosis (Fig.3). Inclusion bodies were not observed in some lesions with more than 15 to 20 days of clinical onset. Detachment of the dermal layer and necrosis with mild to moderate perivascular inflammatory infiltrate of lymphocytes, plasma cells, neutrophils and macrophages were observed in some areas. Adjacent dermis showed the same type of infiltrate. Eosinophilic extensive areas of serous material and cellular debris above the affected epidermis were prominent.

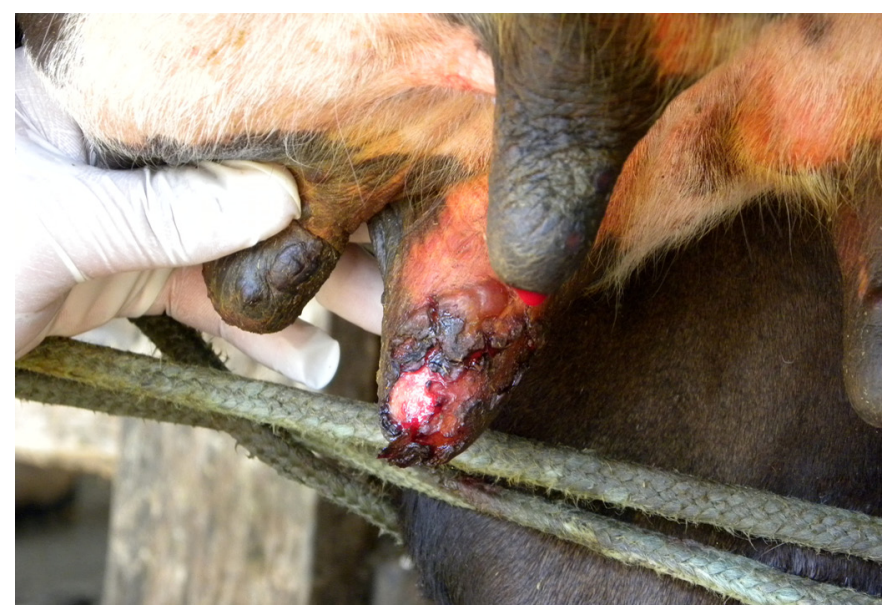

Fig.1. Dairy cow with severe swelling of teats. In addition, vesicles, papules and ulcers focally extensive are observed (Outbreak 6).

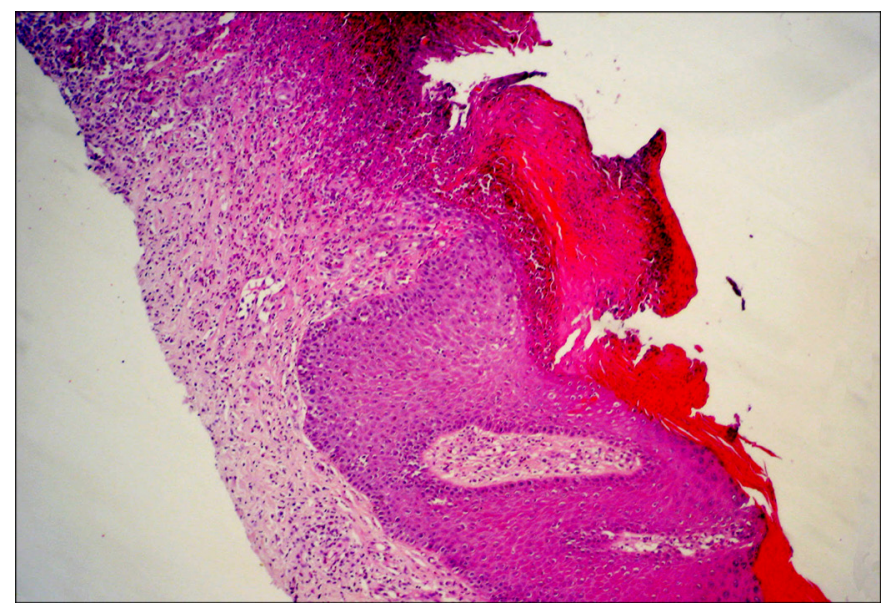

Fig.2. Area of acanthosis and ortokeratotic hyperkeratosis with adjacent focally extensive ulcer, formation of crusts and moderate dermal perivascular inflammatory infiltrate (Outbreak 6). HE, obj. $4 \mathrm{x}$.

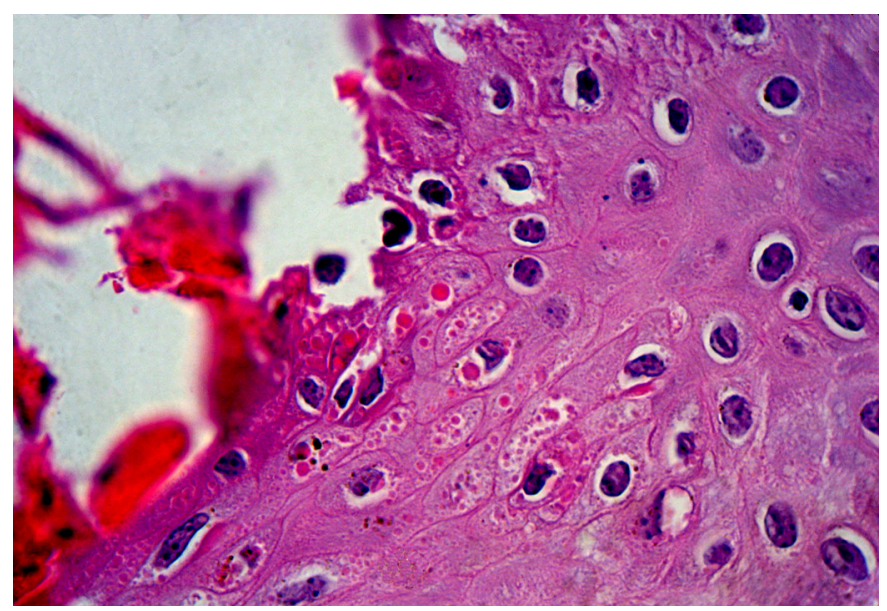

Fig.3. Numerous 3-8 $\mu$ m, circular, eosinophilic inclusion bodies in the cytoplasm of the keratinocytes in the skin of an affected cow (Outbreak 6). HE, obj.40x.

In some outbreaks, affected cows showed a mild to moderate clinical improvement upon local treatment with 3\% iodine solution for 7 to 10 consecutive days. Furthermore, in outbreak 6 , the affected cows were treated with systemic antibiotics and analgesics, with mild clinical improvement. The farmers of the outbreaks 1-3 and 6 informed that similar clinical signs were observed in dairy cows in other farms of the region or in nearby counties, within the same season.

In all outbreaks, one (outbreaks 2-5 and 8) or two (outbreaks 1, 6 and 7) persons that had contact with the affected cows presented concomitant vesicular disease, totaling 11 human cases. The symptoms included body pain, headache, general malaise, fever $\left(39.5-40^{\circ} \mathrm{C}\right)$ and severe lesions, such as $1-1,5 \mathrm{~cm}$ in diameter, sometimes umbilicated pustules, vesicles, ulcers and scabs, mainly in the hands and fingers (all outbreaks) (Fig.4), but also affecting, in isolated cases, the neck (outbreak 1), lips (outbreak 3), nose (outbreak 3) and arm (outbreak 2). Many affected milkers remained 2-3 days away from work. As a rule, human lesions began after 


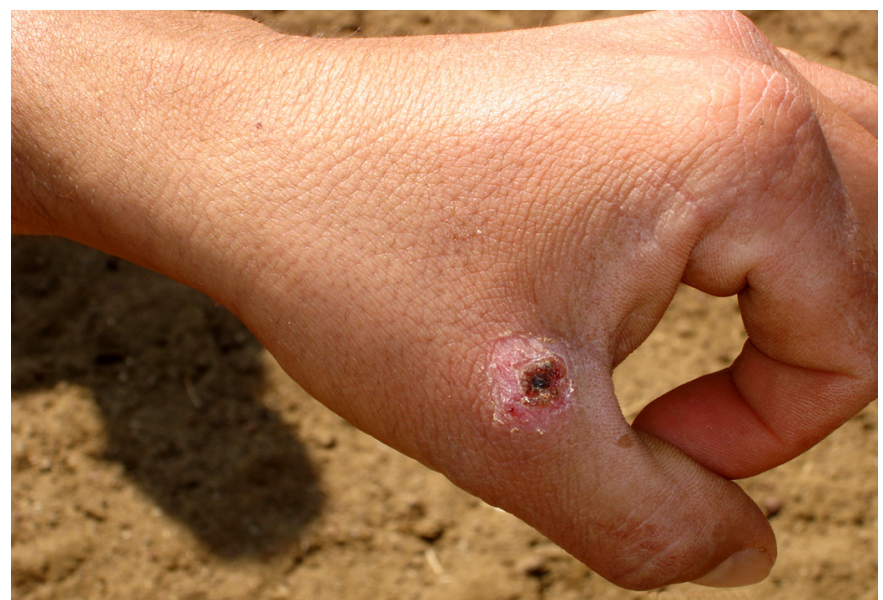

Fig.4. Milker presenting an ulcer with scab on the hand (Outbreak 2).

milking affected cows, starting with painful papules and pustules which progressed to ulcerative and scabby lesions by days 2 to 4 . Treatment with antipyretic and analgesic was performed in most human cases. According to the owners, similar signs have never been observed before in the animals or people in the region. In all cases, the affected people aged from 18 to 31 years-old.

Laboratory diagnosis (PCR, virus isolation and/or serology) was performed in all outbreaks. PCR to $v g f$ gene of $\mathrm{OPV}$ resulted positive in scabs samples from all outbreaks. PCR to parapoxvirus resulted negative in all samples. Samples from outbreaks 6 and 8 were submitted to nucleotide sequencing, and the results showed high identity (about 98 to $99 \%$ ) with VACV. In other outbreaks, the PCR performed (Fonseca et al. 1998) suggested VACV as the etiologic agent of vesicular lesions. Serology to OPV were performed by ELISA to samples from outbreaks 1, 2, 3, 4, 5 e 7 and resulted positive. Virus-neutralizing was performed to samples from outbreak 6 , and neutralizing antibodies titers ranging from 8 to 64. Infectious virus was isolated from scabs collected from animals of outbreak 6, and PCR was performed to confirm the virus species. In summary, molecular diagnosis confirmed VACV involvement in all outbreaks.

\section{DISCUSSION}

In all outbreaks, VACV-associated disease was suspected based on epidemiological, clinical and pathological findings, and confirmed by laboratory diagnosis. Other agents associated with vesicular disease were considered and, subsequently discarded as VACV was confirmed as the etiological agent. The histopathological findings were, in particular, very suggestive of poxvirus infection, but the laboratory tests (virus isolation, PCR for $v g f$ gene of OPV and serology) were crucial to establish the definitive diagnosis. Other suspected agents would include FMD, which is currently eradicated from most Brazilian regions, Vesicular Stomatitis virus (VSV), Pseudocowpox virus (PCPV) infection (Cargnelutti et al. 2012b), Bovine Viral Diarrhea Virus (BVDV), which is endemic in the country, Bovine herpesvirus type 2 (BoHV-2) and Bovine papular stomatitis virus (BPSV) infections (Sant'Ana et al. 2012).
The pathological lesions caused by VACV are similar to those observed in other bovine vesicular diseases, e.g. FMD and VS. The typical alterations of FMD are only seen in those animals which are examined at the peak of the disease and vesicles form on the inner side of the lips and cheeks, gums, hard palate, dental pad and tongue. These vesicles can coalesce and produce bullae which may be $5-6 \mathrm{~cm}$ diameter. After rupture of bullae, ulcerated area may show an intensely red and moist base (Brown et al. 2007). Gross lesions of FMD are very similar to those of VSV. Microscopic alterations of VSV include cell swelling, spongiosis, epithelial cell necrosis and inflammation in the mucosa and underlying lamina propria. However, histologically, there are no inclusion bodies in FMD and VS, differently from what was noted in VACV lesions (Brown et al. 2007). BVDV can cause scabs and erosive and shallow ulcerative lesions, especially in the alimentary system, nares and muzzle of cattle affected with mucosal disease.

Generalized dermatitis has been observed in cattle infected by BVDV (Ferreira et al. 2008), yet teat lesions have not been described. Infection by BoHV-2 causes herpes mammilitis and lesions affect frequently the teats of lactating cows and include swollen and painful lesions, $1-2 \mathrm{~cm}$ diameter plaques, ulcers and crusts. Vesicles are not common in this infection. Prominent intranuclear eosinophilic inclusion bodies and epithelial syncytia are microscopic findings characteristic of BoHV-2 mammilitis (Brown et al. 2007).

There is a marked similarity among the gross and microscopic lesions associated with VACV, PCPV and BPSV infection (Brown et al. 2007, Cargnelutti et al. 2012b, Sant'Ana et al. 2012). In all these diseases, the gross and histological lesions are useful to complement the diagnosis, but the laboratory confirmation by virus detection through molecular or isolation techniques is essential for the definitive diagnosis.

In the present study, vesicular disease associated with VACV infection was observed affecting dairy cows and milkers in many southern and central mesoregions of the Goiás State. Based on the information collected from milkers, farmers and veterinarians of the affected counties, other outbreaks of similar disease affecting cows and humans were noticed, but there was no notification or etiologic confirmation in most of the cases. It is possible that VACV was also involved in some of these outbreaks, since it was demonstrated to be circulating in the region.

The disease was observed in lactating dairy cows from all affected herds and calves from 5 of 8 outbreaks). The morbidity rate was higher in cows and ranged between 8.2 to $100 \%$ and in four outbreaks this rate was higher than $75 \%$ (100\% in two outbreaks). High rate of morbidity was also described by some authors (Lobato et al. 2005, reviewed by Lemos \& Riet-Correa 2007). There were heifers in six affected farms, but they were not affected. Probably, the daily and intensive hand milking of the cows favors the prompt virus transmission among these animals.

The VACV infections diagnosed in the present report occurred in the dry season of the year. Other outbreaks by PPV and VACV in cattle were also observed in the same 
period (Lobato et al. 2005, Sant'Ana et al. 2012). Probably, in the outbreaks 1-3, the proximity between the farms and the fact of the daily collection of produced milk in the three properties by the same truck could have favored the dissemination of the infection.

Gross lesions noted in the cows and calves of the present study were similar to the ones described in other reports of VACV disease observed in Brazil (Trindade et al 2003, Lobato et al. 2005, Schatzmayr et al. 2009a). More severe lesions affecting also the perineal region and the inner thigh were described in other investigations (Reviewed by Lemos \& Riet-Correa 2007). Few investigations has described the histopathological alterations associated with VACV in cattle (Saurini et al. 2010).Additionally, histological lesions caused by this virus are very similar those observed in the infections by parapoxvirus (Cargnelutti et al. 2012b, Sant'Ana et al. 2012). An isolated outbreak of vesicular disease in horses associated to VACV (Brum et al. 2010) also presented comparable lesions with the ones observed in the present study.

Humans, noticeably milkers, were affected in all outbreaks, and developed painful lesions in the hands, fingers and in other regions of the body, mainly neck and face. Similar clinical symptoms were observed in humans beings in outbreaks described in other Brazilian states (Nagasse-Sugahara et al. 2004, Megid et al. 2008, Silva et al. 2008, Schatzmayr et al. 2009b). Sudoresis, anorexia, toxemia and lymph node swelling were also observed in some human cases (Silva et al. 2008, Schatzmayr et al. 2009a, 2009b). In comparison with other zoonotic vesicular disease, VACV infection appears to affect more severely and systematically the humans that have contact with the affected cattle (Büttner \& Rziha 2002, Silva-Fernandes et al. 2009). In the present investigation, the affected humans beings stayed two or three days out of your job under medical care. These results show the zoonotic importance of this disease in the studied region. In all the outbreaks, the affected humans were exclusively young or young adults (18 to 31 years old).

The results of the present investigation demonstrate that VACV infection is present and perhaps disseminated in some regions in the State of Goiás. The study shows that the detailed pathological findings associated to epidemiological, clinical, and virological aspects are useful diagnostic tools for the confirmation of the VACV infection in cattle.

\section{REFERENCES}

Abrahão J.S., Guedes M.I.M., Trindade G.S., Fonseca F.G., Campos R.K., Mota B.F., Lobato Z.I.P., Siva-Fernandes A.T., Rodrigues G.O.L., Lima L.S., Ferreira P.C.P., Bonjardim C.A. \& Kroon E.G. 2009. One more piece in the VACV ecological puzzle: could peridomestic rodents be the link between wildlife and bovine vaccinia outbreaks in Brazil? PLoS One 4:e7428.

Abrahão J.S., Drumond B.P., Trindade G.S., da Silva-Fernandes A.T., Ferreira J.M, Alves P.A., Campos R.K., Siqueira L., Bonjardim C.A., Ferreira P.C. \& Kroon E.G. 2010. Rapid detection of Orthopoxvirus by semi-Nested PCR directly from clinical specimens: a useful alternative for routine laboratories. J. Med. Virol. 82:692-699.

Brown C.C., Baker D.C. \& Barker I.K. 2007. Alimentary system, p.1-296. In: Maxie M.G. (Ed), Jubb, Kennedy, and Palmer's Pathology of domestic animals. Vol.2. ${ }^{\text {th }}$ ed. W.B. Saunders, Edinburgh. 771p.
Brum M.C., Anjos B.L., Nogueira C.E.W., Amaral L.A., Weiblen R. \& Flores E.F. 2010. An outbreak of orthopoxvirus-associated disease in horses in southern Brazil. J. Vet. Diagn. Invest. 22:143-147.

Büttner M. \& Rziha H.-J. 2002. Parapoxviruses: From the lesion to the viral genome. J. Vet. Med. B 49:7-16.

Cargnelutti J.F., Schmidt C., Masuda E.K., Braum L.D., Weiblen R. \& Flores E.F. 2012a. Vaccinia viruses isolated from cutaneous disease in horses are highly virulent for rabbits. Microb. Pathog. 52:192-199.

Cargnelutti J.F., Flores M.M., Teixeira F.R., Weiblen R. \& Flores E.F. 2012b. An outbreak of pseudocowpox in fattening calves in southern Brazil. J. Vet. Diagn. Invest. 24:437-441.

Damaso C.R., Esposito J.J., Condit R.C. \& Moussatché N. 2000. An emergent poxvirus from humans and cattle in Rio de Janeiro State: Cantagalo virus may derive from Brazilian smallpox vaccine. Virology 277:439-449.

D’Anunciação L., Guedes M.I.M., Oliveira T.L., Rehfeld I., Bonjardim C.A., Ferreira P.P., Trindade G.S., Lobato Z.P., Kroon E.G. \& Abrahão J.S. 2012. Experimental evidence of horizontal transmission of Vaccinia virus between bovines and rodents. Vector-Borne and Zoonotic Dis. 12:61-64.

Esposito J.J. \& Fenner F. 2001. Poxviruses, p.2885-2981. In: Knipe D.M., Howley P.M., Griffin D.E., Lamb R.A., Martin M.A., Roizman B. \& Straus S.E. (Eds), Fields Virology. Lippincott Williams and Wilkins, Philadelphia. 3280p.

Ferreira L.C.L., Flores E.F., Driemeier D., Melo O. \& Lemos R.A.A. 2008. Doença das mucosas associada à dermatite generalizada em bovinos, Mato Grosso do Sul. Pesq. Vet. Bras. 28:285-292.

Fonseca F.G., Lanna M.C.S., Campos M.A.S., Kitajima E.W., Peres J.N., Golgher R.R., Ferreira P.C.P. \& Kroon E.G. 1998. Morphological and molecular characterization of the poxvirus BeAn 58058. Arch. Virol. 143:11711186.

Guedes M.I.M.C., Rehfeld I.S., Oliveira T.M.L., Assis F.L., Matos A.C.D., Abrahão J.S., Kroon E.G. \& Lobato Z.I.P. 2012. Detection of Vaccinia virus in blood and faeces of experimentally infected cows. Transbound Emerg. Dis. (In publication)

Kroon E.G., Mota B.E., Abraão J.S., Fonseca F.G. \& Trindade G.S. 2011. Zoonotic Brazilian Vaccinia virus: from field to therapy. Antiviral Res. 92:150-163.

Inoshima Y., Morooka A. \& Sentsui H. 2000. Detection and diagnosis of parapoxvirus by the polymerase chain reaction. J. Virol. Methods 84:201-208.

Leite J.A., Drumond B.P., Trindade G.S., Lobato Z.I.P., Fonseca F.G., Santos J.R., Madureira M.C., Guedes M.I.M.C., Ferreira J.M.S., Bonjardim C.A., Ferreira P.C.P. \& Kroon E.G. 2005. Passatempo virus, a vaccinia virus strain, Brazil. Emerg. Infect. Dis. 11:1935-1938.

Lemos R.A.A. \& Riet-Correa F. 2007. Infecções víricas da pele do úbere em bovinos, p.147-152. In: Riet-Correa F., Schild A.L., Lemos R.A.A. \& Borges J.R.J. (Eds), Doenças de Ruminantes e Equídeos. Vol.1. 3aㅡ ed. Palotti, Santa Maria. 719p.

Lobato Z.I.P., Trindade G.S., Frois M.C.M., Ribeiro E.B.T., Dias G.R.C., Teixeira B.M., Lima F.A., Almeida G.M.F. \& Kroon E.G. 2005. Surto de varíola bovina causada pelo vírus vaccínia na região da Zona da Mata Mineira. Arq. Bras. Med. Vet. Zootec. 57:423-429.

Megid J., Appolinário C.M., Langoni H., Pituco E.M. \& Okuda L.H. 2008. Vaccinia virus in humans and cattle in southwest region of São Paulo State, Brazil. Am. J. Trop. Med. Hyg. 79:647-651.

Mercer A.A., Schmidt A. \& Weber 0. 2007. Poxviruses. Birkhauser Advances in Infectious Diseases, Birkhauser Verlag, Basel. 441p.

Nagasse-Sugahara T.K., Kisielius J.J., Ueda-Ito M., Curti S.P., Figueiredo C.A., Cruz A.S., Silva M.M.J., Ramos C.H., Silva M.C.C., Sakurai T. \& Salles-Gomes L.F. 2004. Human vaccinia-like virus outbreaks in São Paulo and Goiás States, Brazil: virus detection, isolation and identification. Revta Inst. Med. Trop., São Paulo, 46:315-322.

Rivetti Jr. A.V., Guedes M.I.M.C., Rehfeld I.S., Oliveira T.M.L., Matos A.C.D., Abrahão J.S., Kroon E.G. \& Lobato Z.I.P. 2013. Bovine vaccinia, a systemic infection: Evidence of fecal shedding, viremia and detection in lymphoid organs. Vet. Microbiol. 162:103-111. 
Sant'Ana F.J.F., Rabelo R.E., Vulcani V.A.S., Cargnelutti J.F. \& Flores E.F. 2012. Bovine papular stomatitis affecting dairy cows and milkers in midwestern Brazil. J. Vet. Diagn. Invest. 24:442-445.

Saurini N.O., Quixabeira J., Ubiali D., Stragliotto A., Silva M.I.V., Souza M.A., Colodel E.M. \& Pescador C.A. 2010. Diagnóstico de varíola bovina através da técnica de imuno-histoquímica em bovinos de leite no Estado de Mato Grosso. 6 Endivet, Campo Grande, MS, p.116. (Resumo).

Schatzmayr H.G., Simonetti B.R., Abreu D.C., Simonetti J.P., Simonetti S.R., Costa R.V.C., Gonçalves M.C.R., D’Andréa P.S., Gerhardt M., Silva M.E.V., Farias-Filho J.C. \& Barth O.M. 2009a. Animal infections by vaccinia-like viruses in the state of Rio de Janeiro: An expanding disease. Pesq. Vet. Bras. 29:509-514.

Schatzmayr H.G., Costa R.V.C., Gonçalves M.C.R., Barreto D.F., Batista V.H., Silva M.E.V., Brust L.A.C. \& Barth O.M. 2009b. Infecções humanas causadas por poxvírus relacionados ao vírus vaccinia no Brasil. Revta Soc. Bras. Med. Trop. 42:672-676.

Silva A.C., Reis B.B., Ricci Junior J.E.R., Fernandes F.S., Côrrea J.F. \& Schatzmayr H.G. 2008. Infecção em humanos por varíola bovina na microrre- gião de Itajubá, Estado de Minas Gerais: relato de caso. Revta Soc. Bras. Med. Trop. 41:507-511.

Silva-Fernandes A.T., Travassos C.E.P.F., Ferreira J.M.S., Abrahão J.S., Rocha E.S.O., Viana-Ferreira F., Santos J.R., Bonjardim C.A., Ferreira P.C.P. \& Kroon E.G. 2009. Natural human infections with Vaccinia virus during bovine vaccinia outbreaks. J. Clin. Virol. 44:308-313.

Smith G.L. 2007. Genus Orthopoxvirus: Vaccinia virus, p.1-46. In: Mercer A.A., Schmidt A. \& Weber O. (Eds), Poxviruses. Birkhauser Advances in Infectious Diseases. Birkhauser Verlag, Basel. 441p.

Trindade G.S., Fonseca F.G., Marques J.T., Nogueira M.L., Mendes L.C.N., Borges A.S., Peiró J.R., Pituco E.M., Bonjardim C.A., Ferreira P.C.P. \& Kroon E.G. 2003. Araçatuba virus: a vaccinialike virus associated with infection in humans and cattle. Emerg. Infect. Dis. 9:155-160.

Trindade G.S., Drumond B.P., Guedes M.I.M.C., Leite J.A., Mota B.E.F., Campos M.A., Fonseca F.G., Nogueira M.L., Lobato Z.I.P., Bonjardim C.A., Ferreira P.C.P. \& Kroon E.G. 2007. Zoonotic Vaccinia virus infection in Brazil: Clinical description and implications for health professionals. J. Clin. Microbiol. 45:1370-1372. 